\title{
CURRENT HEALTH STATUS AND CARE PRACTICES AMONG THE RETIRED ELDERLY PROFESSORS OF TRIBHUVAN UNIVERSITY
}

\author{
Bishnu G.C. *
}

\begin{abstract}
This study tries to find out the current health status and the care practices of the retired elderly Professors of Kathmandu. Descriptive research design has been followed and all together $\mathbf{3 0}$ male and $\mathbf{1 0}$ female retired professors were selected conveniently. Structured questionnaire was used to collect the data and information. This study reveals that, most of the respondents (around 50\%) were from 60-69 years young-old age group. In most cases, economic condition (around 90\% have their own pension), marital life (around $\mathbf{6 2 . 5 \%}$ are currently married) and family support (more than $90 \%$ ) of the respondents were satisfactory about their current health status. Their physical health seems good but they were still suffering from the backache $(\mathbf{1 0 0 \%})$, poor eye sight $(\mathbf{8 0} \%)$, pain around the waist $(60 \%)$, gastritis $(60 \%)$ and headache $(40 \%)$ which was often in elderly age due to auto immune and wear and tear theory. It was found that some of them were suffering from different chronic and acute diseases but they were cared and supported by their family members in their hard time. They had practiced regular medical checkups due to satisfactory family life and economic status.
\end{abstract}

Keywords: Physiological process, organisms, immunity power, biological component, currently married.

\section{INTRODUCTION}

Tribhuwan University (TU) is the first national institution of higher education in Nepal. It was established in 1959 A.D. There are 38 central departments, 4 research centers, 60 constituent campuses, 7950 teaching faculty and 7122 nonteaching staffs in all over the country (TU, 2013).

The teaching faculties are categorized as teaching assistant, assistant professor, associate professor and professor who work hard until retirement. The TU service commission has designed a plan for age limit services. The aged 63 years has been decided as a retirement age for teaching and administrative staffs of TU. The contribution of retired teaching faculties is

* Mr. G.C. is an Assistant Professor, Central Department of Education, T.U. 
remarkable in the history of Nepalese education system and development. Now they can be remembered as a retired elderly professor in Nepali education. Reaching an old age is a natural phenomenon of human life cycle. Aging is a physiological process. It is progressive, generalized impairment of body functions resulting in loss of adaptive response to stress and increased risk of age-related diseases. Because of this, death is the ultimate consequence of aging (Maharjan, 2012). Demographic figures of both world and Nepal show the elderly population is growing faster. In 2015, Elderly population shared 8percent of the world's population (UNFPA, 2017). Likewise, Nepal has 8.3 percent elderly population. The growth rate of elderly is 2 percent, which exceeds the total population growth rate of 1.35 percent. The decrease in fertility and mortality rate has contributed the growth in elder population (CBS, 2014).

There are various factors that make a person old. Decrease in physical strength, increase in mental tension, decrease in immunity power and getting sick to a large extent are the major feature that make a person aged. There are many concerns and problem of elderly people. They are concerned for their health, diminished social status and insecurities. Caring of elderly people is a welfare scheme that provides meaningful support for the elderly people with a view to make their health physically and mentally sound and to continue the emotional aspects of their life (Poudel, 2005).

Older people who take on a large number and variety of activities and roles will have a more positive older age, adjust to ageing better, and be more satisfied with their lives (Cary \& Kinney, 2001 as cited in Bisht, 2003). Human body consists of a natural immunity power that saves from the condition of disease attack. But this capacity is not same in all people. This capacity depends on the person's balance diet, environment, health care and use of service etc. If the individual immunity power has decreased the diseases can easily attack him and makes him patient that brings negative changes in his physical capacity as well as ageing. In course of wearing and tearing the body or organs of an individual, ageing appears in individuals (Donalelle et al., 1988 as cited in Maharjan, 2000). The problem with the elderly people is vulnerability to degenerative diseases. They have little or no money for health check up. So, there should be access to prompt and reliable health facility. In this study area, there are problems to manage the health problem of elders.Park (1991) while ageing merely stands for growing old, senescence, an expression used for the deterioration in the vitality or the lowering of the biological efficiency that accompanies ageing with the passage of time leads certain changes to take place in an organism 
which lead for the most part to deteriorate and eventually lead to the death of organisms and the disabilities are considered as incident to it. Hurlock (1967), old people mainly face the problems of lack of money, health problems and social acceptances. Most of the old persons have no medical insurance and health insurance for their medical treatment when they are at sick.

The sex differentials in disability and mortality result from differences in the prevalence of chronic disease for males and females. The risk of many acute, lethal diseases is greater among men (e.g. myocardeal infarct, many types of cancer) with the risk of many chronic degenerative processes (e.g. rheumatoid arthritis, osteoporosis, diabetes) higher for females (Manton, 1989 as cited in Binstock, 1990). UN (2002) The United Nation designated the year 1999 as the "International Year of Older People". It draws attention to the independence and interdependence of the generations the factors being to create a dynamic and reciprocal exchange of encouragement, ennoblement, and caring at old age. Such reciprocity enacted in family, community and society at large is the animating principle leading towards a society for all ages as the theme of the year.

NEPAN and Help Age International (2008) launched a study on Voice of Old Age in Nepal. This was a qualitative research. In this research Participatory Rural Appraisal (PRA) tools had been utilized. The researcher found that elderly persons suffer from diseases such as asthma, cough and cold, conjunctivitis, gastritis, fever, diarrhea, scabies, skin allergy, prolapsed uterus, stomachache, sinusitis, respiratory problem, tuberculosis etc. Most of the women from the poor families suffer from prolapsed uterus. There are many studies in the field of elderly population but a very few studies have been conducted in the field of health status of retired elderly professors. Retired elderly professor have wide experience, wisdom and they are expertise ones. It is necessary to take elders as issue sincerely from the society and nation. Elders are the sea of the knowledge, experiences and wealth of the nation, so it is very important to study of health status of retired elderly professor.

Elderly people were found to be vulnerable to physical, social, emotional and socio-economic problems. It is necessary to study, their socio-economic and health status to promote and maintain their status and to make future health status better. The occupational health hazards may create health problem of retired elderly professor as a burning issue in the world. In the context of Nepal, there are many kinds of health problem facing by retired elderly professor. So this study intends to find out the solution of 
following research questions. What are the current health problems of the retired elderly professors? What are the factors that corresponds physical, mental and social health status? What extent the elders cared by self, family and others in health problems?

\section{METHODOLOGY}

The researcher has used the descriptive research design with quantitative techniques. All the retired elderly professors from different faculties, TU within the Kathmandu valley (Kathmandu, Lalitpur and Bhaktapur district) were the population of this study. The convenient sampling technique was applied for the study. There were altogether 40 respondents including of 30 male and 10 female retired professors as a sample was selected for this study. For the purpose of data collection, the structured questionnaire was developed on the basis of research reports, journals, books, websites etc. In structured questionnaire, both closed and open ended questions were consisted. The structured questionnaire was divided into two sections. The first section of the questionnaire was based on health problems of the respondents and the second section with health care practices by self and family level. After collecting the required information and data, they were carefully checked and verified for reducing the possible errors. The collected data was tabulated in a master chart. Simple statistical method, such as frequency, percentages etc. was applied for analysis and interpretation of data. The information collected from the questionnaire was analyzed with the help of previously published theory, research and studies.

\section{RESULTS AND DISCUSSION}

This study is completely based on primary data collected by the researcher in 2018 A.D. and used some data table for completion of this research article.

\section{Age and Sex Distribution of the Respondents}

In the demographic study, the age and sex are considered as a major biological component. Age is a living years while the sex is a natural determinant in any population composition. Normally population is divided into different age groups amongst the elders are categorized as follows for analysis and interpretation. Younger-old(60-69 years), older-old (70-79 years) and oldest-old ( 80 years above). Following data table presents the age and sex distribution of the respondents. 
Table 1: Distribution of Retired Elderly Professors on the Basis of Age and Sex

\begin{tabular}{|l|c|c|c|c|c|c|}
\hline \multirow{2}{*}{$\begin{array}{l}\text { Age } \\
\text { group }\end{array}$} & \multicolumn{2}{|c|}{ Male } & \multicolumn{2}{c|}{ Female } & \multicolumn{2}{c|}{ Total } \\
\cline { 2 - 7 } & Number & Percent & Number & Percent & Number & Percent \\
\hline $60-64$ & 3 & 10 & 1 & 10 & 4 & 10 \\
\hline $65-69$ & 12 & 40 & 4 & 40 & 16 & 40 \\
\hline $70-74$ & 8 & 26.6 & 2 & 20 & 10 & 25 \\
\hline $75-79$ & 5 & 16.6 & 2 & 20 & 7 & 17.5 \\
\hline 80 above & 2 & 6.6 & 1 & 10 & 3 & 7.5 \\
\hline Total & $\mathbf{3 0}$ & $\mathbf{1 0 0}$ & $\mathbf{1 0}$ & $\mathbf{1 0 0}$ & $\mathbf{4 0}$ & $\mathbf{1 0 0}$ \\
\hline
\end{tabular}

Source: Field survey, 2018

Both male and female retired professors aged 60-64 years old were 10 percent, 65-69 years old were 40 percent, 70-74 years old were 25 percent, $75-79$ years old were 17.5 percent and 80 years\& above years were 7.5 percent (Table-1). In this study, most of the respondents were 65 to 69 years old. This data is quite similar to national data. So, most of the respondents were in younger- old category (CBS, 2014).

\section{Respondents Marital Status}

Marriage is social phenomenon in Nepalese context. Marriage system keeps its greater value in family and social system. Marriage means a legal union between a man and a woman. The researcher had collected information about the marriage status of respondents. Marital status possesses vital importance in elderly life. Marital status has a strong effect on the situation of both elderly men and women in Nepal regarding family care and support. It determines a woman's position within the family as well as her status in the society.

Table 2: Distribution of the Respondent by Marital Status

\begin{tabular}{|l|c|c|}
\hline Marital Status & Respondents & Percent \\
\hline Currently married & 25 & 62.5 \\
\hline Never married & 1 & 2.5 \\
\hline Divorced/ separated & 2 & 5.0 \\
\hline Widow/widower & 12 & 30.0 \\
\hline Total & $\mathbf{4 0}$ & $\mathbf{1 0 0 . 0 0}$ \\
\hline
\end{tabular}

Source: Field study, 2018

Among 40 respondents, the higher proportion of belonged to currently married group, which consisted 62.5 percent likewise widow/ widower were 30 percent, divorced/separated were 5 percent and rest 2.5 percent were life time never married. There were more married who stayed together than divorced/separated. The reason might be males remarried when they were divorced/ separated or widowed, which was granted by the society also. It was revealed that widow/widower proportion was higher 
than divorced and never married most of the respondents had lost their spouses respectively (Table-2).

\section{Personal Income Sources}

Income is the main factor, which supports the life of living standards. Every individual needs to get engaged in different occupation for his or her income. Regarding the respondents all were the retired person and almost all had their own pension. Though the respondents were of old aged, so, outdoor field work and hard work was not reliable for them. Following data presents the real conditions of sources of income.

Table 3: Distribution of Personal Source of Income

\begin{tabular}{|l|c|c|c|c|c|}
\hline $\begin{array}{c}\text { Source of } \\
\text { income }\end{array}$ & Pension & Business & $\begin{array}{c}\text { Bank } \\
\text { interest }\end{array}$ & House rent & Others \\
\hline Number & 36 & 15 & 36 & 29 & 20 \\
\hline Percentage & 90 & 37.5 & 90 & 72.5 & 50 \\
\hline
\end{tabular}

Source: Field survey, 2018

Note: The percentage may exceed 100 due to multiple responses.

Almost 90 percent of respondents got pension as the main source of income while 90 percent also had the bank interest, 72.5percent had house rent, 37.5percent had business and 50percent had other source of income like research, publication and trainer. Most of the respondents had good source of income through their regular source pension and bank interest. Sources of income could play significant role in life style and health status.

\section{Expenses Purposes with Sufficiency}

Everybody have their own need and demand for survive. The people purchase verities of good in their daily life. Somebody take marketing and purchases as a big hobby in their life style. The expenses level varies from person to person in terms of life style and needs. In the elderly age, expenses might be high in different headings and create problems to manage.

Table 4: Distribution of Sufficiency and Purposes of Expenses

\begin{tabular}{|l|c|c|}
\hline \multicolumn{1}{|c|}{ Sufficient Expenses } & Respondents & Percent \\
\hline Yes & 28 & 70.00 \\
\hline Not so much & 8 & 20.00 \\
\hline No & 4 & 10.00 \\
\hline Purposes of Expenses & 23 & 57.50 \\
\hline Household work & 6 & 15.00 \\
\hline For children & 26 & 65.00 \\
\hline For health care & 12 & 30.00 \\
\hline Pocket money & 5 & 12.50 \\
\hline For pleasure & \multicolumn{2}{|c|}{} \\
\hline
\end{tabular}

Source: Field survey, 2018

Note: The percentage may exceed 100 due to multiple responses. 
About 70percent respondents were satisfied with their expenses in different work similarly only 10percent said they were not satisfied with their expenses in life. Maximum respondents had used their expenses in their health care which was around 65percent of total expenses followed by 57 percent in household work and 30percent in pocket money expenses. The data presents that maximum respondents were very much conscious about on their health so they had spent more money in their health cares.

\section{Respondents Common Health Problems}

With the increase of age an elder person becomes physically, mentally and socially weak. The resist power against disease is going to minor infection. Due to this, disease like asthma, joint pain, eye or ear defect and so on occurs.

In the elderly period, most of the people might suffer from different kinds of health problems. The different kinds of health problems of the respondents were analyzed in subsequent parts.

Table 5: Distribution of the Respondents by Common Health Problems

\begin{tabular}{|c|c|c|c|c|}
\hline \multirow{3}{*}{ Health Problem } & \multicolumn{4}{|c|}{ Sex } \\
\hline & \multicolumn{2}{|c|}{ Male } & \multicolumn{2}{|c|}{ Female } \\
\hline & Number & Percent & Number & Percent \\
\hline Poor eye sight & 20 & 66.6 & 8 & 80.0 \\
\hline Pain around the waist & 25 & 83.3 & 6 & 60.0 \\
\hline Backache & 21 & 70.0 & 10 & 100.0 \\
\hline Partial loss of hearing & 16 & 53.3 & 3 & 30.0 \\
\hline RTI/asthma & 8 & 26.6 & 2 & 20.0 \\
\hline Scabies/skin allergy & 6 & 30.0 & 4 & 40.0 \\
\hline Headache & 12 & 40.0 & 4 & 40.0 \\
\hline Swelling of legs/pain & 8 & 26.6 & 4 & 40.0 \\
\hline Gastritis & 28 & 93.3 & 6 & 60.0 \\
\hline Abdominal pain & 3 & 10.0 & 2 & 20.0 \\
\hline Prolapsed uterus & - & 0.0 & 3 & 30.0 \\
\hline Urinary system/ sexuality & 3 & 10.0 & 1 & 10.0 \\
\hline
\end{tabular}

Source: Field survey, 2018

Note: *The percentage may exceed 100 due to multiple responses. 
Maximum retired professors have the problem of poor eye-sight, waist pain, backache and gastritis. The proportion of male respondents with the problems of poor eye sight is found less than the female respondents $(66.6 \% \mathrm{Vs} 80 \%)$ followed by pain around the waist with 83.3 percent and 60percent in male and female respectively. The proportion of male respondents with the problems of backache is found less than the female respondents (70\% Vs 100\%) but the proportion of female respondents with the problems of gastritis is found less than the male respondents $(93.3 \% \mathrm{Vs}$ $60 \%$ ). Out of the total respondents, 53.3percent male and 30percent female reported suffering from partial loss of hearing which is common among all of the elders in Nepal.

Headache problem is reported by both male and female percentage is equal, which consists of 40percent. Swelling of legs/pain problem is reported by male and female 26.6percent and 40percent respectively. Scabies/skin allergy problem is reported by 30percent and 40percent respectively. Respiratory problem/asthma is reported by 26.6 percent for male and 20percent for female. Prolapsed uterus is related with female respondents and it is reported by 30percent of female respondents, which is seen as major health problem nowadays in Nepal among elderly females. Avery few proportion had faced abdominal pain which was 10 percent in male and 20percent in female retired elderly professors (Table-5).

\section{Medical Facilities inside the Home or Visit outside for Care Practices}

Home, hospital, clinic, Dhami/Jhankri etc. are the main places for the treatment. To improve health condition, either they get medical facilities inside the home or they go to place and take the services and facilities of health problem. Proper treatment is needed to manage these health problems. The following table shows the place of treatment of the respondents.

Table 6: Distribution of the Respondent by Place for Treatment

\begin{tabular}{|l|c|c|}
\hline Place for treatment & Respondents & Percent \\
\hline In home & 8 & 20.0 \\
\hline In home with doctor & 20 & 50.0 \\
\hline Hospital/health post & 36 & 90.0 \\
\hline Clinic/nursing home & 12 & 30.0 \\
\hline Dhami/Jhankri & 4 & 10.0 \\
\hline
\end{tabular}

Source: Field survey, 2018

Note: The percentage may exceed 100 due to multiple responses.

About 90 percent respondents had visited hospital/health post for treatment of their immediate health problems. Around 50percent respondents 
reported treatment in home with private doctors while clinic/nursing home is used by 30percent, in home with family member doctors by 20 percent and 10percent believed Dhami/Jhankri to treatment their health problems.

\section{Cares by the Family Members in Weak Health}

The best family care to the elderly is the traditions in Nepalese society. But many people get less opportunity from their own home or family level. The family members respect and they take the elders as their head of the family, so most of the family tries to give good service and care to their elders at home and the family level.

Table7: Distribution of Cares by the Family Members in Weak Health

\begin{tabular}{|l|c|c|c|c|c|c|}
\hline \multirow{2}{*}{ Family Members } & \multicolumn{2}{|c|}{ Male } & \multicolumn{2}{c|}{ Female } & \multicolumn{2}{c|}{ Total } \\
\cline { 2 - 7 } & Number & Percent & Number & Percent & Number & Percent \\
\hline Spouses & 26 & 87.5 & 8 & 80.0 & 34 & 85.0 \\
\hline Daughter & 12 & 40.0 & 4 & 40.0 & 16 & 40.0 \\
\hline Son/Daughter in law & 24 & 80.0 & 6 & 60.0 & 30 & 75.0 \\
\hline Care taker & 2 & 5.0 & 1 & 10.0 & 3 & 7.5 \\
\hline Self & 16 & 40.0 & 4 & 40.0 & 20 & 50.0 \\
\hline
\end{tabular}

Source: Field survey, 2018.

Note: The percentage may exceed 100 due to multiple responses.

Almost 87.5percent male and 80percent female are cared by their currently living spouses while both 40percent are cared by daughter, 80 percent male and 60percent female are cared by son/daughter in law, both 40percent are cared by own self and 5percent male and 10percent female are cared by care taker when they got illness (Table-7). It is revealed that the health condition of elders might be improved if they are cared by their family members. The first health personals are needed for rearing and caring and the second by the family members in weak health.

\section{CONCLUSION}

The respondents were mostly local residents within the Kathmandu Valley. Hence, most of the elder professors had good economic status, fixed assets as well as own pension, house rent and personal business. To attain this condition, they personally made efforts as well as their families supported as being currently married life with living children. A good condition of physical, mental and social health could be attributed to condition such as better diet, cleanliness and efforts for being active. People who have lack of balance diet, proper environment and proper health care facilities are suffered by different sorts of health problem which is proved by the 
application of the autoimmune theory. Similarly, people who work a lot suffer from the pain around the waist, backache, headache which is often justified by the wear and tear theory.

It is found that some of the elders were cared and supported by their family members like spouse, daughter, son /daughter in law etc. in their hard time or in the time of illness. They have practiced better healthy life due to satisfactory level of income, happy marital life and proper family support during weak health.

\section{ACKNOWLEDGEMENTS}

This research was funded by The Research Center, Rectors' Office, Tribhuvan University. The researcher would like to express his gratitude to the centre and concerned respondents for their kind supports and co operations.

\section{REFERENCES}

Binstock, G. (1990). Handbook of ageing and social science. New York: Academic Press.

Bisht, P. S. (2003, 8-19 December). Ageing and the elderly population in Nepal. A Paper Presented at Population and Development Training Programme. Kathmandu.

Central Bureau of Statistics (2014).Population monograph of Nepal (Vol. 1). Kathmandu: Authors.

Hurlock, E. B. (1967). Development psychology. New Delhi: Hilt Publishing Company Ltd.

Maharjan, S. K. (2000). Ageing source book of population education. Kathmandu: Population Education Unit, Education Faculty, T.U.

Maharjan, S. K. and Khanal S.P. (2012) Fundamentals of population education, Kirtipur: Quest Publication.

NEPAN (2008). Voice of old age. Participatory Research Report. Kathmandu: NEPAN and Help Age International.

Park, J. E. and Park, K. (1991). Textbook: Preventive and social medicine. (13 ${ }^{\text {th }}$ ed.). Jabalpur: M/s Banarsidas Bhanot Publishers.

Poudel, N. (2005). Problems of elderly population. The Kathmandu Post, P. 7.

Tribhuvan University. (2013). TU today, Kathmandu: TU.

UNFPA (2017) World population data sheet. New York: Author.

United Nation (2002) Madrid international plan of action on ageing, Madrid: Author. 